\section{PERLINDUNGAN DAN UPAYA HUKUM DALAM MENEKAN MARAKNYA PERKAWINAN ANAK DI INDONESIA ${ }^{1}$ \\ Oleh: Gabrila Christy Mumek ${ }^{2}$}

\begin{abstract}
ABSTRAK
Tujuan dilakukannya peneltian ini adalah untuk mengetahui bagaimana perlindungan hukum terhadap perkawinan anak di bawah umur dan bagaimana upaya hukum dalam menekan maraknya perkawinan anak di Indonesia. Dengan menggunakan metode penelitian yuridis normatif, disimpulkan: 1. Anak merupakan generasi muda penerus bangsa yang harus dijaga dan dilindungi oleh keluarga, masyarakat juga negara maupun undangundang yang berlaku. Perkawinan anak merupakan pelanggaran hukum khususnya terhadap undang-undang yang berlaku dan merupakan bentuk pelanggaran HAM yang dapat merenggut hak-hak anak. Penetapan batasan usia minimal yang tidak jelas untuk perkawinan mendorong terjadinya praktik perkawinan anak dan undang-undang yang berlaku tidak menjamin perkawinan anak di Indonesia dapat dicegah atau ditolak. 2 . Pemerintah sepakat untuk menaikkan batasan usia menjadi 19 (sembilan belas) tahun bagi pria dan wanita untuk menikah lewat disahkannya undang-undang yang baru, yaitu Undang-Undang Nomor 16 Tahun 2019 Tentang Perubahan Atas Undang-Undang Nomor 1 Tahun 1974 Tentang Perkawinan.

Kata kunci: Perlindungan, Upaya Hukum, Perkawinan Anak.
\end{abstract}

\section{PENDAHULUAN}

\section{A. Latar Belakang}

Pemerintah sudah membuat undangundang baru yang sah tentang batasan usia minimal bagi pria dan wanita untuk melakukan perkawinan. Tahun ini telah ditanda tangani Undang-Undang Nomor 16 Tahun 2019 Tentang Perubahan Atas Undang-Undang Nomor 1 Tahun 2014 Tentang Perkawinan yang sebelumnya telah disahkan dalam Rapat Paripurna DPR RI. Perubahan utama ada pada Pasal 7 Ayat (1) Undang-Undang Nomor 16

\footnotetext{
1 Artikel Skripsi. Dosen Pembimbing: Dr. Anna S. Wahongan, $\mathrm{SH}, \mathrm{MH}$; Wilda Assa, $\mathrm{SH}, \mathrm{MH}$

2 Mahasiswa pada Fakultas Hukum Unsrat, NIM. 16071101620
}

Tahun 2019, yaitu "Perkawinan hanya diizinkan apabila pria dan wanita sudah mencapai umur 19 (sembilan belas) tahun".

Apabila dalam perkawinan ditemukan pasangan yang berusia kurang dari umur 19 tahun seperti dimaksud dalam undang-undang tersebut, maka ada beberapa hal yang perlu dilakukan. Orang tua pihak pria dan wanita dapat meminta dispensasi ke pengadilan dengan memberikan alasan serta bukti pendukung yang kuat sebagaimana tertuang dalam Pasal 7 Ayat (3) Undang-Undang Nomor 16 Tahun 2019 tersebut.

Maraknya perkawinan anak di Indonesia menunjukkan bahwa tingkat pendidikan dan kesadaran hukum di Indonesia masih kurang. Perkawinan anak dapat terjadi karena persetujuan dari kedua pihak atau disebabkan keadaan yang memaksa, didukung oleh berbagai faktor seperti latar belakang pendidikan, ekonomi, sosiokultural, agama dan lain-lain. Maraknya perkawinan anak ini bisa dicegah lewat berbagai upaya yang dapat terwujud apabila ada kerjasama antara lembaga formal dan informal di Indonesia.

Berdasarkan uraian di atas, maka penulis ingin mengangkat judul tentang "PERLINDUNGAN DAN UPAYA HUKUM DALAM MENEKAN MARAKNYA PERKAWINAN ANAK DI INDONESIA".

\section{B. Rumusan Masalah}

1. Bagaimana perlindungan hukum terhadap perkawinan anak di bawah umur?

2. Bagaimana upaya hukum dalam menekan maraknya perkawinan anak di Indonesia?

\section{Metode Penelitian}

Jenis penelitian yang digunakan penulis dalam penulisan karya ilmiah yang berupa skripsi ini adalah penelitian yuridis normatif, yaitu dilakukan dengan cara mengkaji berbagai peraturan yang bersifat formal seperti UndangUndang dan literatur-literatur yang bersifat konsep teoritis yang kemudian dihubungkan dengan permasalahan yang menjadi pokok pembahasan skripsi ini.

\footnotetext{
3 Undang-Undang Nomor 16 Tahun 2019 Tentang Perubahan Atas Undang-Undang Nomor 1 Tahun 2014 Tentang Perkawinan.
} 


\section{PEMBAHASAN}

\section{A. Perlindungan Hukum Terhadap Perkawinan Anak Di Bawah Umur}

UU Perkawinan sebenarnya tidak mengenal adanya perkawinan anak atau pernikahan dewasa. UU Perkawinan hanya memberi batasan minimal usia ideal bagi warga negara untuk menikah, yaitu setelah berumur 21 tahun, baik laki-laki maupun perempuan. Hanya saja, UU Perkawinan membolehkan laki-laki berumur di bawah 19 tahun dan perempuan di bawah 16 tahun untuk menikah, selagi mendapat dispensasi dari pengadilan, dalam hal ini Pengadilan Agama.

Di sisi lain, ada sejumlah regulasi yang mendefenisikan anak dengan batasan usia di bawah 18 tahun. Sebut saja UU Perlindingan Anak, UU Kesehatan, UU Pendidikan Nasional dan sekitar 20 regulasi lainnya, semua mendefiniskan anak dalam pengertian tersebut. Dengan demikian, peristiwa menikah di bawah 18 tahun disebut sebagai perkawinan anak.

Tulisan ini mencoba untuk mendudukkan persoalan hukum_perkawinan di bawah umur_di Indonesia dan mengapa sejumlah pihak mengecam praktik pernikahan anak, serta bagaimana mengharmonisasi regulasi terkait pernikahan di bawah umur tersebut.

Pernikahan dini sejatinya sudah banyak terjadi di sejumlah wilayah di Indonesia. Badan Pusat Statistik pada tahun 2017 menyebut 25,71 persen perempuan berusia 20-24 tahun menikah saat umurnya kurang dari 18 tahun. Artinya, 1 dari 4 perempuan Indonesia menikah di usia anak.

Perkawinan anak itu merata hampir di semua provinsi. Sebanyak 23 provinsi dari 34 provinsi memiliki prevalensi pernikahan anak lebih tinggi dari prevalensi nasional. Prevalensi pernikahan anak tertinggi ada di Kalimantan Selatan, yaitu sebanyak 4 dari 10 perempuan dan terendah di Daerah Istimewa Yogyakarta 1 dari 10 perempuan. (Harian Kompas, 29 April 2018).

Untuk daerah Sulawesi Selatan, menurut data dari Bidang Urais dan Binsyar Kanwil Kemenag Provinsi Sulawesi Selatan, pada tahun 2017 angka pernikahan di bawah umur lebih 500 kali dari total 75.000 peristiwa nikah. Angka tertinggi di Kota Makassar, Kab. Gowa, dan Kab. Bulukumba. (Hasil wawancara dengan Kasi
Kepenghuluan Kanwil Kemenag Prov. Sulawesi Selatan).

\section{B. Perlindungan Dan Upaya Hukum Dalam Menekan Maraknya Perkawinan Anak Di Indonesia}

Anak adalah bagian dari pembangunan nasional yang perlu dijaga keberadaannya dan dilindungi hak-haknya. Pembangunan perlindungan anak merupakan investasi untuk meningkatkan pertumbuhan ekonomi dan kesejahteraan masyarakat melalui perbaikan kualitas hidup anak sebagai generasi penerus bangsa. Upaya tersebut dapat diwujudkan dengan memastikan anak tumbuh dan berkembang secara optimal, serta terlindungi dari segala bentuk kekerasan dan diskriminasi.

Pemerintah merumuskan tujuh agenda pembangunan nasional 2020-2024 dimana salah satu agendanya adalah meningkatkan Sumber Daya Manusia (SDM) berkualitas dan berdaya saing, yang dititiberatkan pada pemenuhan layanan dasar. Agenda ini dapat memperkuat pelaksanaan perlindungan sosial, meningkatkan kualitas anak, mengentaskan kemiskinan, meningkatkan produktivitas dan daya saing SDM, serta mengendalikan pertumbuhan penduduk.

Anak perempuan remaja cenderung lebih rentan terhadap praktik tradisional yang berbahaya seperti perkawinan anak dibandingkan anak laki-laki. Satu dari setiap sembilan anak perempuan menikah sebelum usia 18 tahun, dan anak-anak perempuan dari keluarga termiskin lima kali lebih mungkin menikah pada usia sangat dini dibandingkan teman-teman mereka yang lebih kaya.

Perkawinan anak, selain melanggar hak-hak anak dengan memaksa mereka berhenti sekolah, juga mengakibatkan kemiskinan antargenerasi, merusak pendidikan jangka panjang mereka, kemampuan untuk mencari nafkah, dan ironisnya juga dapat bertambah jumlahnya.

Di sisi hukum, kekerasan terhadap anak masih terjadi (perkosaan, perkawinan paksa), dan sistem keadilan untuk anak-anak belum memprioritaskan perlindungan bagi semua anak yang berurusan dengan hukum.

Prosedur administrasi publik yang kompleks dan kurangnya kewenangan yang diamanatkan untuk perlindungan anak mengakibatkan 
kesulitan dalam menyediakan layanan yang efektif untuk anak-anak yang rentan. Selain itu, sekitar $17 \%$ anak-anak di bawah usia 18 tahun tidak memiliki akta kelahiran, yang menyebabkan mereka sulit untuk mengakses layanan utama. ${ }^{4}$

Memandang pentingnya perkawinan, berbagai upaya dilakukan agar ada peraturan atau undang-undang yang dapat mengatur tentang perkawinan. Salah satunya upaya hukum yang dilakukan, yaitu membentuk Undang-Undang Perkawinan pada tahun 1974. Masa pembentukan hingga terjadinya UndangUndang Perkawinan melewati tiga periode, yaitu:

a. Masa Penjajahan

Terbentuknya peraturan hukum perkawinan baru pada tahap tuntutan formal sehingga mengakibatkan kaum wanita lebih menderita. Undang-undang yang berisi tentang hukum perkawinan tidak berhasil dibuat sampai berakhirnya masa penjajahan pemerintah Hindia Belanda.

b. Orde Lama

Keinginan untuk mempunyai UndangUndang Perkawinan pada masa orde lama belum juga terwujud karena golongan Kristen dan warga Negara keturunan Eropa juga Cina telah memiliki kodifikasi hukum perkawinan maka jarang terjadi permasalahan yang sulit dalam perkawinan mereka. ${ }^{5}$

Hukum perkawinan yang dipedomani oleh umat Islam masih tersebar dalam beberapa kitab fikih munakahat. Usaha perbaikan perilaku perkawinan terus dilanjutkan melalui instruksi Menteri Agama Nomor 4 Tahun 1974 yang isinya menganjurkan kepada petugas pencatat nikah, talak dan rujuk untuk mencegah perkawinan di bawah umur, menertibkan kembali soal poligami, talak dan rujuk. Hal tersebut dilakukan agar sesuai ajaran hukum Islam namun sampai periode kepemimpinan orde lama berakhir,

\footnotetext{
${ }^{4}$ Unicef, Child Protection.

${ }^{5}$ Taufiqurrohman Syahuri, Legislasi Hukum Perkawinan Di Indonesia, Pro Kontra Pembentukannya Hingga Putusan Mahkamah Konstitusi, Kencana Prenada Media Group, Jakarta, 2013, hal. 104.
}

undang-undang tentang perkawinan belum juga terbentuk. $^{6}$

c. Orde Baru

Sidang parlemen (DPR-GR) pada tahun 1967-1971 kembali membahas Rancangan Undang-Undang Perkawinan, yaitu:

1) Rancangan Undang-Undangan Perkawinan Umat Islam berasal dari Departemen Agama, yang diajukan kepada DPR-GR bulan Mei tahun 1967.

2) Rancangan Undang-Undang

Ketentuan-Ketentuan Pokok

Perkawinan dari Departemen

Kehakiman yang diajukan kepada DPR-GR bulan September $1968 .^{7}$

Terbentuknya Undang-Undang Perkawinan tidak menjamin perkawinan itu dilakukan sesuai undang-undang yang berlaku. Perkawinan bawah umur atau perkawinan anak tetap terjadi karena hukum dan undang-undang yang berlaku berbenturan dengan budaya atau adat istiadat masyarakat setempat juga faktor ekonomi dan tingkat pengetahuan yang rendah tentang perkawinan. Hal ini juga dikarenakan adanya dispensasi menurut kondisi yang diajukan yang dalam pelaksanaannya masih memungkinkan praktik perkawinan anak terjadi.

Pada tahun 2014, berbagai koalisi lembaga sosial dan masyarakat sipil yang bergerak di bidang perlindungan perempuan dan anak mengajukan permohonan pengujian ketentuan batas usia perkawinan dalam Undang-Undang Nomor 1 Tahun 1974 Tentang Perkawinan terhadap Undang-Undang Dasar Tahun 1945. Meskipun demikian, permohonan ini ditolak oleh Mahkamah Konstitusi melalui Putusan Nomor 30-74/PUU-XII/2014.

Mahkamah Konstitusi dalam pertimbangan hukumnya menyatakan bahwa batasan usia minimum merupakan kebijakan hukum terbuka (open legal policy). Menurut majelis hakim batas usia minimal perkawinan dapat diubah oleh lembaga legislatif sesuai dengan perkembangan zaman.

Pembatasan usia perkawinan pada asasnya tidak dilarang dan selama tidak bertentangan

\footnotetext{
${ }^{6}$ Ibid.

${ }^{7}$ Ibid. hal. 208.
} 
dengan UUD 1945. Selain itu, tidak ada jaminan yang dapat memastikan bahwa dengan ditingkatkannya batas usia kawin untuk wanita dari 16 (enam belas) tahun menjadi 18 (delapan belas) tahun, akan mengurangi angka perceraian, menanggulangi permasalahan kesehatan, maupun meminimalisir permasalahan sosial lainnya. ${ }^{8}$

Mahkamah Konstitusi Republik Indonesia selanjutnya mengeluarkan Putusan Mahkamah Konstitusi Nomor 22/PUU-XV/2017 yang salah satu pertimbangan Mahkamah Konstitusi dalam putusan tersebut, yaitu "Namun tatkala pembedaan perlakuan antara pria dan wanita itu berdampak pada atau menghalangi pemenuhan hak-hak dasar atau hak-hak konstitusional warga negara, baik yang termasuk ke dalam kelompok hak-hak sipil dan politik maupun hak-hak ekonomi, pendidikan, sosial, dan kebudayaan, yang seharusnya tidak boleh dibedakan semata-mata berdasarkan alasan jenis kelamin, maka pembedaan demikian jelas merupakan diskriminasi."

Pertimbangan yang sama juga disebutkan pengaturan batas usia minimal perkawinan yang berbeda antara pria dan wanita tidak saja menimbulkan diskriminasi dalam konteks pelaksanaan hak untuk membentuk keluarga sebagaimana dijamin dalam Pasal 28B Ayat (1) UUD 1945, melainkan juga telah menimbulkan diskriminasi terhadap pelindungan dan pemenuhan hak anak sebagaimana dijamin dalam Pasal 28B Ayat (2) UUD 1945.

Ketika usia minimal perkawinan bagi wanita lebih rendah dibandingkan pria, maka secara hukum wanita dapat lebih cepat untuk membentuk keluarga. Oleh karena hal tersebut, dalam amar putusannya Mahkamah Konstitusi memerintahkan kepada pembentuk undangundang untuk dalam jangka waktu paling lama 3 (tiga) tahun melakukan perubahan terhadap Undang-Undang Nomor 1 Tahun 1974 tentang Perkawinan.

Perubahan norma dalam Undang-Undang Nomor 1 Tahun 1974 tentang Perkawinan ini menjangkau batas usia untuk melakukan perkawinan, perbaikan norma menjangkau dengan menaikkan batas minimal umur perkawinan bagi wanita. Batas minimal umur

${ }^{8}$ Putusan Mahkamah Konstitusi Nomor: 30-74/PUUXII/2014. perkawinan bagi wanita dipersamakan dengan batas minimal umur perkawinan bagi pria, yaitu 19 (sembilan belas) tahun.

Batas usia dimaksud dinilai telah matang jiwa raganya untuk dapat melangsungkan perkawinan agar dapat mewujudkan tujuan perkawinan secara baik tanpa berakhir pada perceraian dan mendapat keturunan yang sehat dan berkualitas. Diharapkan juga kenaikan batas umur yang lebih tinggi dari 16 (enam belas) tahun bagi wanita untuk kawin akan mengakibatkan laju kelahiran yang lebih rendah dan menurunkan resiko kematian ibu dan anak. Selain itu juga dapat terpenuhinya hak-hak anak sehingga mengoptimalkan tumbuh kembang anak termasuk pendampingan orang tua serta memberikan akses anak terhadap pendidikan setinggi mungkin.

Undang-Undang Republik Indonesia Nomor 16 Tahun 2019 tentang Perubahan Atas Undang-Undang Nomor 1 Tahun 1974 tentang Perkawinan disahkan Presiden pada tanggal 14 Oktober 2019 di Jakarta. Undang-Undang Republik Indonesia Nomor 16 Tahun 2019 tentang Perubahan Atas Undang-Undang Nomor 1 Tahun 1974 tentang Perkawinan diundangkan dan ditempatkan pada Lembaran Negara Republik Indonesia Tahun 2019 Nomor 186.

Penjelasan Atas Undang-Undang Republik Indonesia Nomor 16 Tahun 2019 tentang Perubahan Atas Undang-Undang Nomor 1 Tahun 1974 tentang Perkawinan diundangkan dan ditempatkan dalam Tambahan Lembaran Negara Republik Indonesia Nomor 6401.

Undang-Undang Nomor 16 Tahun 2019 Tentang Perubahan Atas Undang-Undang Nomor 1 Tahun 1974 Tentang Perkawinan

\section{Latar Belakang}

Pertimbangan dalam UU 16 Tahun 2019 tentang Perubahan Atas UU 1 Tahun 1974 tentang Perkawinan adalah:

a. bahwa negara menjamin hak warga negara untuk membentuk keluarga dan melanjutkan keturunan melalui perkawinan yang sah, menjamin hak anak atas kelangsungan hidup, tumbuh, dan berkembang serta berhak atas perlindungan dari kekerasan dan diskriminasi sebagaimana diamanatkan 
dalam Undang-Undang Dasar Negara Republik Indonesia Tahun 1945;

b. bahwa perkawinan pada usia anak menimbulkan dampak negatif bagi tumbuh kembang anak dan akan menyebabkan tidak terpenuhinya hak dasar anak seperti hak atas perlindungan dari kekerasan dan diskriminasi, hak sipil anak, hak kesehatan, hak pendidikan, dan hak sosial anak;

c. bahwa sebagai pelaksanaan atas putusan Mahkamah Konstitusi Republik Indonesia Nomor 22/PUU-XV/2017 perlu melaksanakan perubahan atas ketentuan Pasal 7 Undang-Undang Nomor 1 Tahun 1974 tentang Perkawinan;

d. bahwa berdasarkan pertimbangan sebagaimana dimaksud dalam huruf a, huruf $b$, dan huruf $c$, perlu membentuk Undang-Undang tentang Perubahan atas Undang-Undang Nomor 1 Tahun 1974 tentang Perkawinan.

\section{Dasar Hukum}

Dasar hukum UU 16 Tahun 2019 tentang Perubahan Atas UU 1 Tahun 1974 tentang Perkawinan adalah:

a. Pasal 5 Ayat (1), Pasal 20, dan Pasal 28B Undang-Undang Dasar Negara Republik Indonesia Tahun 1945;

b. Undang-Undang Nomor 1 Tahun 1974 tentang Perkawinan (Lembaran Negara Republik Indonesia Tahun 1974 Nomor 1, Tambahan Lembaran Negara Republik Indonesia Nomor 3019).

\section{Penjelasan Umum Undang-Undang Perubahan Undang-Undang Perkawinan}

Ketentuan Pasal 28B Undang-Undang Dasar Negara Republik Indonesia Tahun 1945, mencantumkan bahwa setiap orang berhak membentuk keluarga dan melanjutkan keturunan melalui perkawinan yang sah serta Negara menjamin hak anak atas kelangsungan hidup, tumbuh, dan berkembang serta berhak atas pelindungan dari kekerasan dan diskriminasi.

Pasal 7 Ayat (1) Undang-Undang Nomor 1 Tahun 1974 menyatakan bahwa perkawinan hanya diizinkan apabila pihak pria mencapai umur 19 (sembilan belas) tahun dan pihak wanita sudah mencapai usia 16 (enam belas) tahun, ketentuan tersebut memungkinkan terjadinya perkawinan dalam usia anak pada anak wanita karena dalam Pasal 1 Angka (1) Undang-Undang tentang Perubahan Atas Undang-Undang Nomor 23 Tahun 2002 tentang Pelindungan Anak didefinisikan bahwa anak adalah seseorang yang belum berusia 18 (delapan belas) tahun, termasuk anak yang masih dalam kandungan.

\section{Isi UU Undang-Undang Nomor 16 Tahun 2019 Tentang Perubahan Atas Undang- Undang Nomor 1 Tahun 1974 Tentang Perkawinan}

Berikut adalah isi UU 16 Tahun 2019 tentang Perubahan Atas UU 1 Tahun 1974 tentang Perkawinan (bukan format asli):

\section{Pasal I}

Beberapa ketentuan dalam Undang-Undang Nomor 1 Tahun 1974 tentang Perkawinan (Lembaran Negara Republik Indonesia Tahun 1974 Nomor 1, Tambahan Lembaran Negara Republik Indonesia Nomor 3019) diubah sebagai berikut:

\section{Pasal 7}

1. Perkawinan hanya diizinkan apabila pria dan wanita sudah mencapai umur 19 (sembilan belas) tahun.

2. Dalam hal terjadi penyimpangan terhadap ketentuan umur sebagaimana dimaksud pada ayat (1), orang tua pihak pria dan/atau orang tua pihak wanita dapat meminta dispensasi kepada Pengadilan dengan alasan sangat mendesak disertai bukti-bukti pendukung yang cukup.

3. Pemberian dispensasi oleh Pengadilan sebagaimana dimaksud pada ayat (2) wajib mendengarkan pendapat kedua belah calon mempelai yang akan melangsungkan perkawinan.

4. Ketentuan-ketentuan mengenai keadaan seorang atau kedua orang tua calon mempelai sebagaimana dimaksud dalam Pasal 6 ayat (3) dan ayat (4) berlaku juga ketentuan mengenai permintaan dispensasi sebagaimana dimaksud pada ayat (2) dengan tidak mengurangi ketentuan sebagaimana dimaksud dalam Pasal 6 ayat (6). 


\section{Pasal 65A}

Pada saat Undang-Undang ini mulai berlaku, permohonan perkawinan yang telah didaftarkan berdasarkan Undang-Undang Nomor 1 Tahun 1974 tentang Perkawinan, tetap dilanjutkan prosesnya sesuai dengan ketentuan Undang-Undang Nomor 1 Tahun 1974 tentang Perkawinan. ${ }^{9}$

\section{Agenda Tujuan Pembangunan Berkelanjutan (Sustanaible Development Goals)}

Selain disahkannya Undang-Undang Perkawinan yang baru, pemerintah bekerja sama dengan negara lain sepakat merumuskan agenda tujuan pembangunan berkelanjutan atau yang disebut Sustanaible Development Goals (SDGs), dimana salah satu tujuannya, yaitu mencapai kesetaraan gender dan memberdayakan semua perempuan dan anak perempuan.

Target yang ingin dicapai, yaitu:

1. Mengakhiri segala bentuk diskriminasi terhadap semua perempuan dan anak perempuan dimana saja.

2. Mengeliminasi segala bentuk kekerasan terhadap perempuan dan anak perempuan pada ruang publik dan privat, termasuk perdagangan (trafficking) dan seksual dan bentuk eksploitasi lainnya.

3. Menghapukan segalasemua praktekpraktek yang membahayakan, seperti perkawinan anak, dini dan paksa dan sunat pada perempuan.

4. Menyadari dan menghargai pelayanandan kerja domestik yang tidak dibayar melalui penyediaan pelayanan publik, kebijakan perlindungan infrastruktur dan sosial serta mendorong adanya tanggung jawab bersama didalam rumah tangga dan keluarga yang pantas secara nasional.

5. Memastikan bahwa semua perempuan dapat berpartisipasi penuh dan mendapat kesempatan yang sama untuk kepemimpinan pada semua level pengambilan keputusan dalam kehidupan politik, ekonomi dan public.

\footnotetext{
${ }^{9}$ Undang-Undang Nomor 16 Tahun 2019 Tentang Perubahan Atas Undang-Undang Nomor 1 Tahun 1974 Tentang Perkawinan.
}

6. Memastikan adanya akses universal terhadap kesehatan seksual dan reproduksi dan hak reproduksi sebagaimana telah disepakati dalam Program Aksi Konferensi Internasional mengenai Kependudukan dan Pembangunan dan Aksi Platform Beijing dan dokumen hasil dari konferensi review keduanya.

7. Melakukan reformasi untuk memberikan hak yang sama bagi perempuan terhadap sumber-sumber ekonomi dan juga akses terhadap kepemilikan dan kontrol terhadap tanah dan bentuk property lainnya pelayanan finansial, warisan dan sumber daya alam, sesuai dengan hukum nasional.

8. Memperbanyak penggunaan teknologi terapan, khususnya teknologi informasi dan komunikasi, untuk mendukung pemberdayaan perempuan.

9. Mengadopsi dan menguatkan kebijakan yang jelas dan penegakkan perundangundangan untuk mendorong kesetaraan gender dan pemberdayaan semua perempuan dan anak perempuan pada semua level. ${ }^{10}$

\section{PENUTUP}

\section{A. Kesimpulan}

1. Anak merupakan generasi muda penerus bangsa yang harus dijaga dan dilindungi oleh keluarga, masyarakat juga negara maupun undang-undang yang berlaku. Perkawinan anak merupakan pelanggaran hukum khususnya terhadap undang-undang yang berlaku dan merupakan bentuk pelanggaran HAM yang dapat merenggut hak-hak anak. Penetapan batasan usia minimal yang tidak jelas untuk perkawinan mendorong terjadinya praktik perkawinan anak dan undang-undang yang berlaku tidak menjamin perkawinan anak di Indonesia dapat dicegah atau ditolak.

2. Pemerintah sepakat untuk menaikkan batasan usia menjadi 19 (sembilan belas) tahun bagi pria dan wanita untuk menikah lewat disahkannya undang-

\footnotetext{
${ }^{10}$ Sustanaible Development Goals, Tujuan 5: Mencapai kesetaraan gender dan memberdayakan semua perempuan dan anak perempuan.
} 
undang yang baru, yaitu Undang-Undang Nomor 16 Tahun 2019 Tentang Perubahan Atas Undang-Undang Nomor 1 Tahun 1974 Tentang Perkawinan.

\section{B. Saran}

1. Undang-undang yang mengatur tentang perkawinan hendaknya dibarengi dengan penyuluhan di berbagai daerah yang tingkat pengetahuan dan kesadaran hukumnya masih rendah.

2. Hukum harus lebih tegas menindak apabila ditemukan adanya perkawinan anak terutama bila tidak memenuhi aturan undang-undang yang berlaku. Kerjasama antara pihak formal dan informal diperlukan mengingat adanya beberapa faktor yang dapat mempengaruhi jalannya Undang-Undang Perkawinan tersebut, antara lain budaya atau tradisi masyarakat setempat, kondisi ekonomi, tingkat pengetahuan atau pendewasaan tentang perkawinan yang masih rendah dan kurangnya kesadaran hukum khususnya di daerah yang angka perkawinan anaknya masih tinggi.

\section{DAFTAR PUSTAKA}

Kependudukan dan Keluarga Berencana Nasional, Kesehatan Reproduksi dan Nikah Dini, Jakarta, 2019.

Badan Pusat Statistik, Perkawinan Usia Anak Di Indonesia 2013 Dan 2015, Edisi Revisi, Jakarta, 2017.

Departemen Pendidikan dan Kebudayaan, Adat dan Upacara Perkawinan Daerah Kalimantan Timur, Proyek Penelitian dan Pencatatan Kebudayaan Daerah Pusat, Jakarta.

Friedman, M. Lawrence, Sistem Hukum; Perspektif IImu Sosial (the Legal System; a Social Science Perspective), Nusa Media, Bandung, 2009.

Gennep van A., The Rites of Passage, London \& Henley: Routledge \& Kegan Paul, 1965.

Gultom, M., Perlindungan Hukum Terhadap Anak, Cet. 2, P. T. Refika Aditama, Bandung, 2010.

Hamdani, A., Risalah Nikah Hukum Perkawinan Islam, Cet. 2, Pustaka Amani, Jakarta, 2002.
Kartono, K., Psikologi Wanita: Gadis Remaja dan Wanita Dewasa, Mandar Madu, Bandung, 1992.

Koesnan, R. A., Susunan Pidana dalam Negara Sosialis Indonesia, Sumur, Bandung, 2005.

Meliala, D. S., Hukum Perdata dalam Perspektif BW, Edisi Revisi Ke-III, Cet. 2, Nuansa Aulia, Bandung, 2013.

Mustofa, A., Kemenag Temukan 82 Anak Nikah Dini, Ternyata Ini Penyebabnya, 2019.

Poerwadarminta, W. J. S., Kamus Umum Bahasa Indonesia, Balai Pustaka: Amirko, 1984.

Pondokbahasa, Apa Bedanya: "Kawin" "Nikah" - "Married" - "Merit", 2008.

Prawirohamidjojo, R. S., Pluralisme dalam Perundang-undangan Perkawinan di Indonesia, Airlangga University Press, 1988.

Program Studi Kajian Gender Universitas Indonesia dan Kementerian Pemberdayaan Perempuan dan Perlindungan Anak Republik Indonesia.

Pudja, G. dan Sudharta, T. R., Manava Dharmasastra, MDS. III, Paramita, Surabaya.

Samosir, D., Hukum Adat Indonesia Eksistensi Dalam Dinamika Perkembangan Hukum di Indonesia, Nuansa Aulia, Bandung, 2013.

Sarlito, S., Teori-Teori Psikologi Sosial, Rajawali, Jakarta, 1991.

Sujana, I. N., Kedudukan Hukum Anak Luar Kawin dalam Perspektif Putusan Mahkamah Konstitusi Nomor 46/PUUVII/2010, Aswaja Pressindo, Yogyakarrta, 2015.

Siregar, B., Keadilan Hukum Dalam Berbagai Aspek Hukum Nasional, Rajawali, Jakarta, 1986,

Syahuri, T., Legislasi Hukum Perkawinan Di Indonesia, Pro Kontra Pembentukannya Hingga Putusan Mahkamah Konstitusi, Kencana Prenada Media Group, Jakarta, 2013.

Tutik, T. T., Pengantar Hukum Perdata, Prestasi Pustaka, Jakarta, 2006.

Utomo, L., Hukum Adat, Rajawali Pers, Jakarta, 2016. 
Yuwana, T. A. dan Maramis, W. F., Dinamika Perkawinan Masa Kini, Cet. II, Dioma, Malang, 2003.

\section{SUMBER-SUMBER LAIN}

Undang-Undang Nomor 1 Tahun 1974 Tentang Perkawinan.

Undang-Undang Nomor 23 Tahun 2002

Tentang Perlindungan Anak.

The Covention on the Rights of the Child (Konvensi Hak-Hak Anak).

Pasal 16 Ayat (2) pada Deklarasi Universal HakHak Asasi Manusia.

Pasal 45 Kitab Undang-Undang Hukum Pidana (KUHP).

Undang-Undang Nomor 39 Tahun 1999 Tentang HAM.

Undang-Undang Nomor 16 Tahun 2019 Tentang Perubahan Atas Undang-Undang Nomor 1 Tahun 2014 Tentang Perkawinan.

Undang-Undang RI Nomor 35 Tahun 2014 Tentang Perlindungan Anak.

Undang-Undang Nomor 4 Tahun 1979 Tentang Kesejahteraan Anak.

Putusan Mahkamah Konstitusi Nomor: 3074/PUU-XII/2014. 